\title{
THE RESOURCE BASIS AS INCENTIVE FOR THE DEVELOPMENT OF RURAL TOURISM - CASE STUDY OF THE MOSLAVINA
}

DOI: http://dx.doi.org/10.18509/GBP.2018.42

UDC: 338.48-44(497.5-22)

\author{
Jelena Lončar ${ }^{1}$ \\ Zdenko Braičić ${ }^{2}$ \\ ${ }^{1}$ University of Zagreb, Faculty of Science, Department of Geography, Croatia \\ ${ }^{2}$ University of Zagreb, Faculty of Teacher Education, Department in Petrinja, Croatia
}

\begin{abstract}
Rural tourism began to develop in Europe much sooner than in Croatia. Despite this, advances have been made and the development of rural tourism has become increasingly interesting since the beginning of the 21 st century. When it comes to the development of rural tourism, the continental part of Croatia possesses specific advantages. One such advantage is the region of Moslavina, located in central Croatia and administratively divided into four cities and nine municipalities. In this study, special focus will be placed on family farms (OPGs) as the bearers of potential for the development of rural tourism; the legal basis for the development of this rural tourism will be analysed in detail, followed by an examination of resources such as agricultural holdings, demographics, social and public infrastructure (cycling and themed routes, internet access, accommodation) and other activities that are vital for tourism in the region in general, but which also constitute the essential preconditions for the development of rural tourism specifically. The working hypothesis of the study is that the existing advantages and preconditions for the development of rural tourism in the Moslavina region have not been properly utilised due to the administrative fragmentation of the region and insufficient investments in various forms of promotion, despite the fact that the available resource basis is ideal not just for rural tourism, but also for many other potential types (hunting, recreational, medical, ecological, etc.).
\end{abstract}

Keywords: Moslavina, resources, family farms, rural tourism.

\section{INTRODUCTION}

In the EU, rural tourism is not a part of the shared policy, but is rather the subject of developmental strategies adopted by each member state individually. It is considered to be a branch of economic activity that is partially within the realm of EU Common Agricultural Policy and various structural funds and initiatives [10].

Looking at the long-term development of agricultural policy and relations in Europe, it becomes obvious that changes in the agrarian structure have resulted in declining real prices in agriculture, due to which farmers needed to find different ways to adapt and protect their economic position. Some chose to expand the scope of their business, increasing production while maintaining the same amount of land. Others, or their family members, chose to repurpose a larger part of their working or capital capacity for activities (outside of or on the holding itself) that are not exclusively agricultural [9, as per Cahill, Hill, 2004].

Ecotourism, agrotourism and other types of rural tourism are often presented as "miracle" solutions when no alternative measures for rural development are available. The 
programmes are widely supported by the European Commission and various agencies for promoting tourism, and they often serve to show how rural tourism can help stimulate the economic activity of businesses and communities that managed to successfully apply for and reap the benefits of such programmes. Considering that only relatively small investments are required and much of the needed support can be found in local knowledge and resources, there are but a few obstacles preventing such activities from being realised. This ultimately results in very high levels of competition, both in the local markets and in the greater, global market [7].

The goal of introducing agrotourism into family farms is to enrich farming and increase the farmer's income, as well as to ensure better sales of their products. In addition, the goal is also to generate motivation in younger family farm members for living in rural areas, and to move the process of farming to a higher level, as well as to preserve the culture and tradition of rural areas [6].

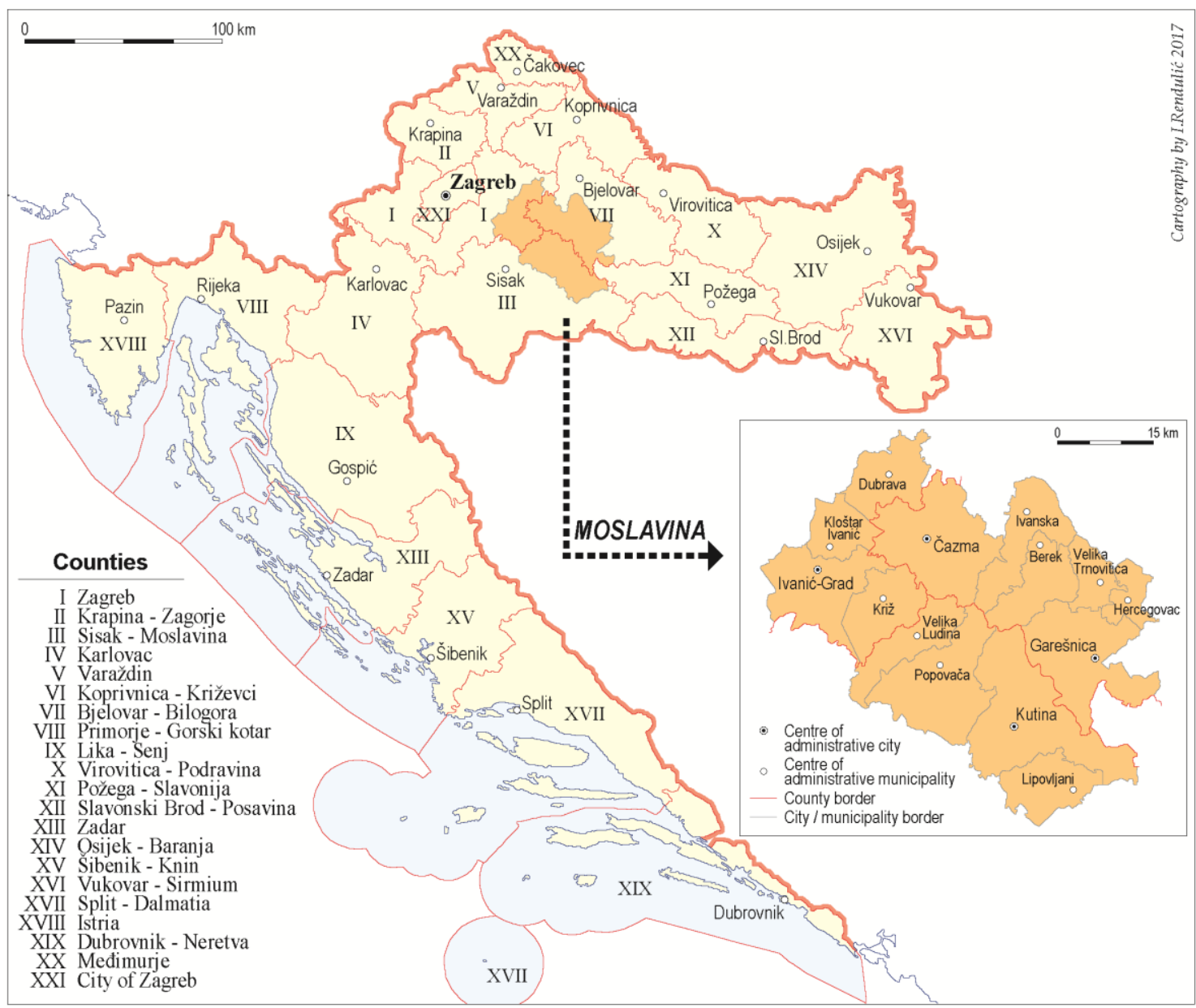

Figure 1. The position of Moslavina within Croatia

Moslavina is among the few regions that are divided between three different counties Zagreb County, Bjelovar-Bilogora County and Sisak-Moslavina County - in the administrative and political division of Croatia. However, despite such legal interventions, Moslavina has managed to preserve its identity. Moslavina is home to four cities and nine municipalities: the cities of Kutina, Ivanić Grad, Garešnica and Čazma, and the municipalities of Berek, Ivanska, Križ, Hercegovac, Dubrava, Velika Ludina, Velika Trnovitica, Kloštar Ivanić and Lipovljani. Unfortunately, the population of the 
analysed area has been decreasing for the past few decades and the average population density is particularly low. The city of Kutina, with 275 people per square kilometre (a value three times greater than the Croatian average), is an exception, with slightly higher values also registered in the city of Ivanic Grad. The remaining cities and municipalities in the region have a particularly low population density (e.g. only 13 people per square kilometre in the municipality of Berek), with values among the lowest in Croatia. Hence, the demographic resources of Moslavina, in line with the overall worrying trend of population decrease across the whole country, do not necessarily make a stable foundation for economic development in general and, by extension, rural tourism.

Operating in said region is LAG (Local Action Group) Moslavina, the goal of which is to use mutual cooperation in order to help increase the standard of living and quality of life in the long term for all the inhabitants of Moslavina - particularly those in the more rural areas of the region.

The natural and geographic features of this area/region are highly favourable because the valuable arable land has relatively few limitations imposed upon it with regards to agricultural production. Humidity levels are moderate across the region, with an intense but rather short period of cold weather occurring annually. The average yearly temperature is $11^{\circ} \mathrm{C}$. The average temperature in the warmer periods is $22{ }^{\circ} \mathrm{C}$, while the median temperature of the colder months ranges from $-3{ }^{\circ} \mathrm{C}$ to $18{ }^{\circ} \mathrm{C}$, depending on the altitude. The annual sunshine duration ranges from 1,700 to 2,000, which allows for significant possibilities with regards to using natural resources as a basis for developing rural tourism in the rural areas of the region [15].

Table 1. Main data on the Moslavina region: administrative division

\begin{tabular}{|c|c|c|c|c|c|c|c|}
\hline \multirow[t]{2}{*}{$\begin{array}{l}\text { Admin. unit in alph. } \\
\text { order }\end{array}$} & \multirow[t]{2}{*}{$\begin{array}{l}\text { Area in } \\
\mathbf{k m}^{2}\end{array}$} & \multicolumn{2}{|c|}{ No. of households } & \multicolumn{2}{|c|}{ Population } & \multicolumn{2}{|c|}{$\begin{array}{l}\text { Population density / } \\
\text { people per } \mathbf{k m}^{2}\end{array}$} \\
\hline & & 2001 & 2011 & 2001 & 2011 & 2001 & 2011 \\
\hline TOTAL & $1,995.69$ & 35,101 & 33,696 & 107,793 & 100,042 & $1,893.05$ & $1,757.71$ \\
\hline City of Kutina & 492.99 & 11,857 & 11,784 & 37,023 & 34,459 & $1,341.26$ & 275.91 \\
\hline $\begin{array}{l}\text { Lipovljani } \\
\text { Municipality }\end{array}$ & 108.70 & 1,330 & 1,144 & 4,101 & 3,455 & 37.73 & 31.78 \\
\hline $\begin{array}{ll}\text { Velika } & \text { Ludina } \\
\text { Municipality } & \end{array}$ & 100.21 & 947 & 885 & 2,831 & 2,625 & 28.25 & 26.20 \\
\hline City of Ivanić Grad & 173.72 & 4,863 & 4,957 & 14,723 & 14,548 & 84.75 & 83.74 \\
\hline Križ Municipality & 118.54 & 2,531 & 2,371 & 7,406 & 6,963 & 62.52 & 58.78 \\
\hline City of Garešnica & 226.54 & 3,920 & 3,610 & 11,630 & 10,472 & 51.34 & 46.23 \\
\hline $\begin{array}{l}\text { Hercegovac } \\
\text { Municipality }\end{array}$ & 50.73 & 935 & 811 & 2,791 & 2,383 & 55.02 & 46.97 \\
\hline Velika Trnovitica & & & & & & & \\
\hline Municipality & 60.80 & 559 & 452 & 1,661 & 1,370 & 27.33 & 22.44 \\
\hline City of Čazma & 240.07 & 2,979 & 2,784 & 8,895 & 8,077 & 37.00 & 33.00 \\
\hline Ivanska Municipality & 119.11 & 1,117 & 954 & 3,510 & 2,911 & 29.46 & 24.43 \\
\hline Berek Municipality & 110.72 & 613 & 521 & 1,706 & 1,443 & 15.40 & 13.03 \\
\hline Dubrava Municipality & 115.95 & 1,683 & 1,524 & 5,478 & 5,245 & 47.00 & 45.00 \\
\hline $\begin{array}{ll}\text { Kloštar } & \text { Ivanić } \\
\text { Municipality } & \end{array}$ & 77.61 & 1,767 & 1,899 & 6,038 & 6,091 & 76.00 & 77.00 \\
\hline
\end{tabular}

As for infrastructure, the road network is sufficiently developed in the majority of the region, with both national and international links. There are 643 sole proprietorships operating in the Moslavina region, amounting to $39.67 \%$ of the total amount of registered businesses. $61.72 \%$ of the sole proprietorships are registered in Kutina, followed by 
companies $(35.66 \%)$, associations $(23.57 \%)$ and cooperatives $(1.11 \%)$. Based on the National Classification of Professions from 2007, the largest share belongs to "other activities" (53.10\%), followed by "agriculture" (28.94\%). The public sector is represented by $2.39 \%$ and the service industry by $6.87 \%$ [15].

The largest number of rural family farms engaged in tourism-related economic activity are located in the northern (more developed) parts of Sisak-Moslavina County, in the Moslavina uplands (moslavačko prigorje) and Lonjsko Polje [3].

\section{AGRICULTURE AND FAMILY FARMS (OPG) AS A BASIS FOR THE DEVELOPMENT OF RURAL TOURISM}

Although there is no official definition, researching the term "agrotourism" will inevitably lead to the following interpretation: an alternative, refined (non-massive, nonaggressive and non-industrialised) form of tourism that respects people and the environment.It is a modern, yet at the same time a traditional form of tourism that is deeply rooted in the local community and based around the local geography, tradition, culture and customs [8].

Table 2. Natural heritage in the Moslavina region - Natura 2000

\begin{tabular}{|c|c|c|c|c|}
\hline $\begin{array}{l}\text { Protection } \\
\text { category }\end{array}$ & Location/name & $\begin{array}{l}\text { Brief description of the location, as } \\
\text { well as activities for improvement or } \\
\text { possible LAG project }\end{array}$ & $\begin{array}{l}\text { Land } \\
\text { area/ha }\end{array}$ & $\begin{array}{l}\text { First year } \\
\text { of } \\
\text { protection }\end{array}$ \\
\hline $\begin{array}{l}\text { Nature } \\
\text { park }\end{array}$ & $\begin{array}{l}\text { Lonjsko } \\
\text { polje/Kutina }\end{array}$ & $\begin{array}{l}\text { Development of partnerships with the } \\
\text { local community }\end{array}$ & $3,385.62$ & 28.3 .1990 \\
\hline $\begin{array}{l}\text { Regional } \\
\text { park }\end{array}$ & $\begin{array}{l}\text { Moslavačka } \\
\text { gora/Kutina }\end{array}$ & $\begin{array}{l}\text { Development of infrastructure required } \\
+ \text { promotion }\end{array}$ & $3,821.67$ & 25.6 .2011 \\
\hline $\begin{array}{l}\text { Nature } \\
\text { park }\end{array}$ & $\begin{array}{l}\text { Lonjsko } \\
\text { polje/Popovača }\end{array}$ & $\begin{array}{l}\text { Development of partnerships with the } \\
\text { local community }\end{array}$ & $5,570.81$ & 28.3 .1990 \\
\hline $\begin{array}{l}\text { Regional } \\
\text { park }\end{array}$ & $\begin{array}{l}\text { Moslavačka } \\
\text { gora/Popovača }\end{array}$ & $\begin{array}{l}\text { Development of infrastructure required } \\
+ \text { promotion }\end{array}$ & $4,044.52$ & 25.6 .2011 \\
\hline $\begin{array}{l}\text { Nature } \\
\text { park }\end{array}$ & $\begin{array}{l}\text { Lonjsko } \\
\text { polje/Lipovljani }\end{array}$ & $\begin{array}{l}\text { Development of partnerships with the } \\
\text { local community }\end{array}$ & $4,143.82$ & 28.3 .1990 \\
\hline $\begin{array}{l}\text { Nature } \\
\text { park }\end{array}$ & $\begin{array}{l}\text { Lonjsko } \\
\text { polje/Velika Ludina }\end{array}$ & $\begin{array}{l}\text { Development of partnerships with the } \\
\text { local community }\end{array}$ & $4,632.47$ & 28.3 .1990 \\
\hline $\begin{array}{l}\text { Regional } \\
\text { park }\end{array}$ & $\begin{array}{l}\text { Moslavačka } \\
\text { gora/Velika Ludina }\end{array}$ & $\begin{array}{l}\text { Development of infrastructure required } \\
+ \text { promotion }\end{array}$ & 355.85 & 25.6 .2011 \\
\hline Forest park & $\begin{array}{l}\text { Žirovnjak } \\
\text { forest/Garešnica }\end{array}$ & $\begin{array}{l}\text { A } 27.04 \text { ha forest and small a fishing } \\
\text { pond by the Garešnica river intended for } \\
\text { rest and relaxation because it has been } \\
\text { declared a forest for specialised use } \\
\text { (sports and recreation) as per the Forest } \\
\text { Act }\end{array}$ & 3.75 & 2002 \\
\hline $\begin{array}{l}\text { Regional } \\
\text { park }\end{array}$ & $\begin{array}{l}\text { Moslavačka } \\
\text { gora/Čazma }\end{array}$ & $\begin{array}{l}\text { Development of infrastructure required } \\
+ \text { promotion }\end{array}$ & $6,247.30$ & 2011 \\
\hline $\begin{array}{l}\text { Specialised } \\
\text { reservation }\end{array}$ & $\begin{array}{l}\text { Siščani and Blatnica } \\
\text { fishing } \\
\text { ponds/Čazma }\end{array}$ & $\begin{array}{l}\text { Development of infrastructure required } \\
+ \text { promotion }\end{array}$ & 761.6 & \\
\hline $\begin{array}{l}\text { Natural } \\
\text { monument }\end{array}$ & $\begin{array}{l}\text { Geological locality } \\
\text { Pleterac/Čazma }\end{array}$ & $\begin{array}{l}\text { Development of infrastructure required } \\
+ \text { promotion }\end{array}$ & & \\
\hline $\begin{array}{l}\text { Specialised } \\
\text { reservation }\end{array}$ & $\begin{array}{l}\text { Zoological } \\
\text { reservation Varoški } \\
\text { lug/Dubrava }\end{array}$ & $\begin{array}{l}\text { Development of infrastructure required } \\
+ \text { promotion }\end{array}$ & 897.03 & $\begin{array}{r}1982, \\
1988\end{array}$ \\
\hline
\end{tabular}




\begin{tabular}{lllrr}
\hline $\begin{array}{l}\text { Specialised } \\
\text { reservation }\end{array}$ & $\begin{array}{l}\text { Forest vegetation of } \\
\text { Varoški }\end{array}$ & $\begin{array}{l}\text { Development of infrastructure required } \\
\text { + promotion }\end{array}$ & 62.49 & 1988, \\
& Dubrava & & & 1996 \\
\hline Total & & & $33,926.93$ & \\
\hline & & & Source: [14]
\end{tabular}

The importance of rural tourism varies from one European country to the next. It is most recognisable in France (Gites de France), Austria (Urlaub am Bauernhof) and Italy (Agriturismo).An organised approach to rural tourism is a matter of increasing importance, as evidenced by the establishment of "EuroGites", the European Federation of Farm and Village Tourism). The Federation brings together 29 professional organisations from 24 European countries, operating more than 180,000 facilities with approximately 2 million beds. In several European countries, national rural tourism associations have also been established - namely, in Austria, Bulgaria, the Czech Republic, France, Hungary, Ukraine and others [10].

Table 3. The status and use of agricultural land and forests as a resource basis in the Moslavina region

\begin{tabular}{|c|c|c|c|c|c|c|c|}
\hline \multirow[t]{2}{*}{ LAU } & \multicolumn{6}{|c|}{ Agricultural land/ha } & \multirow{2}{*}{$\begin{array}{c}\text { Total } \\
\text { forest } \\
\text { area/ha }\end{array}$} \\
\hline & $\begin{array}{c}\text { Total } \\
\text { available } \\
\text { amount }\end{array}$ & Farmed & $\begin{array}{c}\text { Not } \\
\text { farmed }\end{array}$ & $\mathrm{A} 1+\mathrm{A} 2 *$ & A3* & $\mathrm{OA}^{*}$ & \\
\hline $\begin{array}{l}\text { City of } \\
\text { Kutina }\end{array}$ & $13,450.06$ & $5,570.36$ & N/A*** & $1,352.89$ & $12,097.17$ & N/A & $10,311.84$ \\
\hline $\begin{array}{l}\text { City of } \\
\text { Popovača }\end{array}$ & N/A & $7,542.83$ & N/A & N/A & N/A & N/A & $6,406.4$ \\
\hline Lipovljani & $2,191.42$ & $\begin{array}{l}\text { Data not } \\
\text { available }\end{array}$ & N/A & $1,789.49$ & 406.93 & N/A & $1,047.37$ \\
\hline $\begin{array}{l}\text { City of } \\
\text { Ivanić } \\
\text { Grad }^{* *}\end{array}$ & 9,645 & $\begin{array}{l}\text { Data not } \\
\text { available }\end{array}$ & $\begin{array}{l}\text { Data not } \\
\text { available }\end{array}$ & $\begin{array}{l}\text { Data not } \\
\text { available }\end{array}$ & $\begin{array}{l}\text { Data not } \\
\text { available }\end{array}$ & $\begin{array}{l}\text { Data not } \\
\text { available }\end{array}$ & 4,342 \\
\hline $\begin{array}{l}\text { Križ } \\
\text { Municipality }\end{array}$ & $6,553.11$ & 4,202 & 2,132 & 398.21 & $4,988.07$ & 1146.83 & $4,492.16$ \\
\hline Garešnica & $7,706.63$ & $6,410.06$ & $1,296.57$ & $\mathrm{x}$ & $\mathrm{x}$ & $\mathrm{x}$ & $6,796.9$ \\
\hline Hercegovac & 3752.43 & $3,094.758$ & 657.672 & 0 & $\mathrm{x}$ & $\mathrm{x}$ & 308.08 \\
\hline $\begin{array}{l}\text { Velika } \\
\text { Trnovitica }\end{array}$ & $3,872.57$ & $2,728.84$ & $1,143.73$ & 155.89 & $3,096.17$ & 620.51 & $1,945.37$ \\
\hline $\begin{array}{l}\text { City of } \\
\text { Čazma }\end{array}$ & $10,207.35$ & $7,563.00$ & $2,644.35$ & $1,656.61$ & $4,182.61$ & $4,368.13$ & $11,351.27$ \\
\hline $\begin{array}{l}\text { Dubrava } \\
\text { Municipality }\end{array}$ & 7,174 & $6,125.1$ & 135.9 & $1,677.6$ & $3,885.9$ & 561.6 & 2,882 \\
\hline $\begin{array}{l}\text { Kloštar } \\
\text { Ivanić } \\
\text { Municipality }\end{array}$ & $3,990.11$ & $\mathrm{n} / \mathrm{a}$ & $\mathrm{n} / \mathrm{a}$ & 31.1 & $3,959.01$ & 371.9 & $2,558.1$ \\
\hline Total & $68,542.68$ & $43,236.948$ & $8,010.222$ & $6,564.83$ & $32,615.86$ & $7,068.97$ & $52,441.49$ \\
\hline
\end{tabular}

A1* - highly valuable arable land; A2* - valuable arable land, A3* - other arable land, OA* - other agricultural land

**City of Ivanić Grad - the existing contracts should be revised and the areas added together

*** N/A - parts cannot be applied to the LAG

In Croatia rural tourism is defined as stay of tourists in households organised in the form of a rural homestead for the purposes of rest and relaxation; while rural household is a 
rural homestead or family farm (OPG) entered into the Farm Register in accordance with the relevant regulations of the Ministry of Agriculture, which offers hospitality services in a rural household in accordance with the Hospitality and Catering Industry Act [12]. Agrotourism, as a form of rural tourism, is becoming a significant part of the tourist offer in Croatia, as the urban population is attracted to the natural environment that can be found in rural areas or on family farms, and urban rush is replaced with peaceful surroundings. For the development of agrotourism on family farms, great importance is given to good natural and cultural prerequisites such as climate, soil, favourable conditions for the development of agricultural production, and preserved nature and cultural heritage [6].

As one of the resources that can be used for the development of rural tourism, agricultural land owned by OPGs is of vital importance, as it can be used to introduce additional activities to the farm, e.g. tourism. Of the total amount of agricultural land $(98,855.78$ ha), $24.86 \%$ is owned by local administrative units, $28.47 \%$ by the Republic of Croatia, while $46.67 \%$ is owned privately. Of the total amount owned by local administrative units, $21.20 \%$ is being let/sold, while the remaining $72.53 \%$ is intended for use. Of the land owned by the Republic of Croatia, $51.18 \%$ is intended for sale/concession. Privately owned forests make up a $13.04 \%$ share, while $86.96 \%$ is owned by Hrvatske šume.

According to the data provided by the Croatian Bureau of Statistics, of the total amount of agricultural land in the Moslavina region, arable land and gardens make up $72.82 \%$, which is indicative of the main agricultural activities in the area.Approximately $10 \%$ of land is equally divided between pastures, meadows, orchards, vineyards, etc.

According to the available data from the 2003 Agricultural Census, the number of OPGs in the Moslavina region is 17,589. The majority are registered in Kutina $(3,426)$, Garešnica $(2,237)$ and Popovača $(2,201)$. Registered land farmed by the OPGs covers an area of 54,701.90 ha, most of which is registered in Garešnica (7,643 ha) and Kutina $(7,598 \mathrm{ha})$. The total number of family farms with up to 3 ha of registered arable land is 1,908 , followed by 114 farms with $4-5$ ha and 99 farms with up to 5 ha.

24,734.60 ha of agricultural land is covered by the system of incentives for agriculture. The total number of lots is 52.41. According to the data from the Bureau of Statistics, where the category of crops farmed is concerned, orchards, vegetable farming and vineyards cover an area of 1490.19 ha. Orchards make up the largest share (50.98\%), followed by vineyards (36.46\%) and vegetable farming (12.55\%). Moslavina is a famous viticultural region, with vineyards dating back to the Roman era and a strong tradition persisting to this day. The indigenous wines "Moslavac" and "Škrlet" are produced exclusively in the Moslavina region. As for livestock, the analysis covered sheep, goats, cattle and horses, with the total number amounting to 45,961. With $69.69 \%$, sheep are most represented, followed by cattle $(18.47 \%)$, goats $(11.16 \%)$ and horses $(0.68 \%)$. The data on the manner of production, i.e. herding, shows that conventional production makes up the largest share [15].

Competitive agriculture is the basic requirement for the economic sustainability of family farms [11].

Other important factors for quality rural tourism development are: attractive position of the farm, available traffic connections, available telephone connections, available public utilities and services, own agricultural production, fruit-growing, horticulture, farming, viticulture, beekeeping, fish farming and so on, a large number of animals on the farm, the availability of farm buildings, the availability of tourist accommodation, traditional cuisine, sale of own agricultural products, and others [6]. 
The success of agrotourism has been confirmed by several studies conducted in countries in transition, with positive effects registered in the family income and the income of the entrepreneurs who invested in such projects, but also within society as a whole.

Table 4. The state of public infrastructure and quality of life

\begin{tabular}{|c|c|c|c|c|c|c|}
\hline \multirow[t]{2}{*}{ LAU } & \multirow{2}{*}{$\begin{array}{l}\text { Roads } \\
\text { Asphalted } \\
\text { roads/ } \\
\text { km }\end{array}$} & \multirow[b]{2}{*}{$\begin{array}{l}\text { Non- } \\
\text { asphalted } \\
\text { roads/ } \\
\text { km }\end{array}$} & \multicolumn{2}{|l|}{ Water } & \multirow{2}{*}{$\begin{array}{l}\text { ADSL } \\
\% \text { of LAU } \\
\text { area } \\
\text { covered }\end{array}$} & \multirow[b]{2}{*}{$\begin{array}{l}\text { Broadband/ } \\
\text { public wireless } \\
\text { internet/no. of } \\
\text { towns } \\
\text { covered/\% of } \\
\text { LAU area }\end{array}$} \\
\hline & & & $\begin{array}{l}\% \\
\text { covered }\end{array}$ & $\begin{array}{l}\text { No. of } \\
\text { households } \\
\text { connected } \\
\text { to the water } \\
\text { supply }\end{array}$ & & \\
\hline City of Kutina & 256.9 & 44.37 & $76 \%$ & 5,649 & $69.00 \%$ & $85.00 \%$ \\
\hline $\begin{array}{ll}\text { City } & \text { of } \\
\text { Popovača }\end{array}$ & 17.94 & 13.22 & $95 \%$ & 3,610 & $100.00 \%$ & N/A \\
\hline Lipovljani & 33.7 & 0 & $95 \%$ & 442 & & N/A \\
\hline Velika Ludina & 28 & 0 & $92 \%$ & 720 & $100.00 \%$ & \\
\hline $\begin{array}{l}\text { City of Ivanić } \\
\text { Grad }\end{array}$ & 53 & & $99 \%$ & 4,002 & $95 \%$ & $50 \%$ \\
\hline $\begin{array}{l}\text { Križ } \\
\text { Municipality }\end{array}$ & 41.2 & 64.4 & $99 \%$ & 1,559 & $97 \%$ & $50 \%$ \\
\hline Garešnica & 110.7 & 57.1 & $40 \%$ & 1,460 & $100 \%$ & $4 \%$ \\
\hline Hercegovac & 27.1 & 0 & $67 \%$ & 182 & $100 \%$ & $0 \%$ \\
\hline $\begin{array}{l}\text { Velika } \\
\text { Trnovitica }\end{array}$ & 35.8 & 0 & 0 & 0 & $100 \%$ & $0 \%$ \\
\hline City of Čazma & 100.13 & 12.667 & $95 \%$ & & $100 \%$ & $0 \%$ \\
\hline $\begin{array}{l}\text { Dubrava } \\
\text { Municipality }\end{array}$ & 70.7 & 12.9 & $30 \%$ & & $20 \%$ & $5 \%$ \\
\hline $\begin{array}{l}\text { Kloštar Ivanić } \\
\text { Municipality }\end{array}$ & 23 & $\mathrm{n} / \mathrm{a}$ & $95 \%$ & 1,788 & $\mathrm{n} / \mathrm{a}$ & $\mathrm{n} / \mathrm{a}$ \\
\hline Total & 798.17 & 204.657 & & 19,412 & & \\
\hline
\end{tabular}

\section{FAMILY FARMS AS A FACTOR IN RURAL TOURISM DEVELOPMENT}

Over the past few decades, Croatian villages and rural areas have been increasingly impoverished, which has also lead to the destruction of some of their fundamental natural, cultural and social features. However, despite such pessimistic observations, family farms have managed to preserve their uniqueness. The prevailing stance towards the time and space we currently occupy is based around the concept of sustainable development and it is within this context that economies can greatly benefit from the advantages offered by rural areas [7].

Rural areas, the basic resource required for the development of rural tourism, cover $92 \%$ of the territory of the Republic of Croatia.Family farms play the most important role in rural areas as they can utilise their advantages in many different ways, depending on the conditions and specific features in their respective regions [6].

Considering the existing agrarian structure and the extent of participation in the overall production of agricultural products, family farms are the primary organisational and economic unit of agricultural production in the Republic of Croatia. Such a strategic intent is compatible with the general organisational features of contemporary European agriculture, where the majority of production is based around family-operated agricultural units. The state of Croatian agriculture is the result of a large number of adverse historical factors, e.g. unresolved ownership issues, the issue of agricultural land, an inefficient 
incentive system, and proclaimed agricultural reforms with no application in practice [11, as in Franić et al., 2004].

Furthermore, the Agriculture Act defines family farms as independent economic and social entities comprising the adult members of a shared household and based around the ownership and/or use of agricultural resources for the purpose of agricultural activity [1]. However, family farms can also partake in other activities and use them as a source of income or as a supplement to the income made from agriculture. One such activity is rural tourism. The Tourism Act defines rural tourism as "the stay of tourists in households that are organised in the form of a tourist farm (rural homestead) for the purposes of rest and relaxation" [20]. Brščić, Franić and Ružić point to the definition used by the Croatian Chamber of Commerce: "A tourist family farm is a small economic entity located in a region that appeals to tourists; the farm offers indigenous products or services and all the family members are involved in its operation.An agricultural, family or rural farm that offers a tourism-related product or service gains the status of 'tourist family farm'. Tourism on the farm is considered a secondary activity by the owners and their families" [6, as in Brščić, Franić et al., 2010:33]. This form of tourism based around family farms isthe most important form of rural tourism in Croatia [8].

A family farm in Croatia can, therefore, engage in supplementary activities for which it has the adequate resources and meets the necessary requirements, if any are in place for the activity in question, in accordance with the applicable regulations.Types of supplementary activities on family farms include:

- The production of agricultural products and food

- The production of items for general use and products other than food

- The performance of services

- The performance of tourism and hospitality services

- Providing other content and activities [22].

Table 5. The main economic activities in the Moslavina region - sole proprietorships

\begin{tabular}{lrrrrrrr}
\hline \multicolumn{1}{c}{ LAU } & \multicolumn{7}{c}{ Activities of sole proprietorships } \\
\cline { 2 - 9 } & $\begin{array}{l}2015 \\
\text { Total }\end{array}$ & Production & Services & $\begin{array}{c}\text { Hospitality } \\
\text { and } \\
\text { tourism }\end{array}$ & Retail & Transport & $\begin{array}{c}\text { Fishing, } \\
\text { mariculture, } \\
\text { agriculture }\end{array}$ \\
\hline City of Kutina & 300 & 40 & 125 & 35 & 33 & 31 & 12 \\
\hline City of Popovača & 124 & 21 & 41 & 16 & 10 & 17 & 11 \\
\hline Lipovljani & 47 & 6 & 20 & 7 & 2 & 3 & 6 \\
\hline Velika Ludina & 29 & 3 & 9 & 5 & 2 & 2 & 7 \\
\hline Garešnica & 122 & 14 & 31 & 14 & 11 & 9 & 33 \\
\hline Hercegovac & 26 & 3 & 8 & 1 & 2 & 2 & 10 \\
\hline Velika Trnovitica & 5 & 0 & 3 & 2 & 0 & 0 & 0 \\
\hline City of Čazma & 102 & 55 & 103 & 21 & 17 & 50 & 58 \\
\hline $\begin{array}{l}\text { Dubrava } \\
\text { Municipality }\end{array}$ & 63 & 15 & 15 & 4 & 6 & 10 & 7 \\
\hline $\begin{array}{l}\text { Kloštar Ivanić } \\
\text { Municipality }\end{array}$ & 58 & 5 & 15 & 8 & 8 & 3 & 0 \\
\hline Total & 876 & 162 & 370 & 113 & 91 & 127 & 144 \\
\hline
\end{tabular}

The introduction of tourism-related activities in rural areas, i.e. family farms in this case, can help create opportunities for further improving their economic prosperity and making their business more efficient. 
This is also true for the region of Moslavina. It should be noted that various forms of active tourism, e.g. wine roads, horseback riding, cycling and so on, are already being developed in the analysed area. However, due to the specific natural, historical, cultural and traditional features, the area possesses great potential for the development of selected forms of tourism based around the sustainable utilisation of the existing traditional foundations. One of the activities that holds high priority is the creation of recognisable agricultural and craft products for the purposes of further developing the regional tourist offer, achieving a high level of synergy among important branches of the economy, assuring the greater diversification and uniform development of all parts of the region and their inhabitants.

Table 6. The state of the social infrastructure and small public utilities in the Moslavina region LAU Bicycle routes Themed routes

\begin{tabular}{|c|c|c|c|c|c|c|c|c|c|}
\hline \multirow[t]{3}{*}{$\mathbf{L A U}$} & \multicolumn{4}{|c|}{ Bicycle routes } & \multicolumn{5}{|c|}{ Themed routes } \\
\hline & \multicolumn{2}{|c|}{ 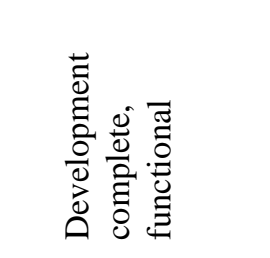 } & \multicolumn{2}{|c|}{ 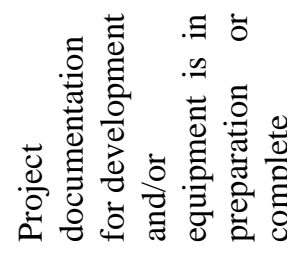 } & \multicolumn{2}{|c|}{ 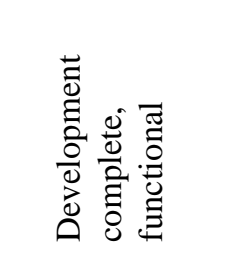 } & \multicolumn{3}{|c|}{ 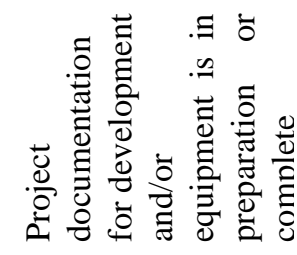 } \\
\hline & Number & $\mathrm{Km}$ & Number & $\mathrm{Km}$ & Number & $\mathrm{Km}$ & Number & $\mathrm{Kn}$ & $\mathrm{m}$ \\
\hline City of Kutina & 9 & 202 & 0 & 0 & 6 & 62 & 0 & & 0 \\
\hline City of Popovača & 8 & N/A & 0 & 0 & 0 & 0 & 0 & & 0 \\
\hline Lipovljani & 1 & 17 & 0 & 0 & 0 & 0 & 0 & & 0 \\
\hline Velika Ludina & 2 & 20 & 0 & 0 & 0 & 0 & 0 & & 0 \\
\hline City of Ivanić Grad & 3 & 104 & 0 & 0 & 2 & 4 & 0 & & 0 \\
\hline Križ Municipality & 2 & 93 & 0 & 0 & 1 & 70 & 0 & & 0 \\
\hline Garešnica & 1 & 2.6 & 0 & 0 & 0 & 0 & 1 & & 0 \\
\hline Kloštar Ivanić & N/A & N/A & 1 & 1,309 & N/A & N/A & N/A & & N/A \\
\hline Total & 26 & 438.6 & 1 & 1,309 & 9 & 136 & 1 & & 0 \\
\hline
\end{tabular}

For a rural household to be able to perform activities related to rural tourism, the type of facility used for such services has to be defined. A facility in a rural household is considered to be a functional unit on the family farm intended for, depending on its type, performing hospitality services, serving food and drinks typical of the area and primarily made from ingredients produced on the farm itself, and providing accommodation and other services related to tourist consumption [18].

Types of facilities in rural households 1. Wine tasting, 2. Excursion site (a facility in which guests are served hot and cold dishes and drinks, with a maximum capacity of 50 guests), 3. Room, 4. Apartment (a facility providingaccommodation that allows the guest to prepare and eat their own food), 4a.Rural holiday home, 5. Camp (a facility in which guests are provided outdoor accommodation and can use camping equipment in a special area intended for that purpose; the camp has to serve food and drinks). Furthermore, each facility is categorised individually. Facilities in a rural household are categorised according to the prescribed requirements related to: accommodation, furnishing, equipment, appliances, maintenance and so on. The facility itself has to be furnished and equipped in line with the tradition of the area in which it is located [18].

In the Moslavina region, of all the listed facilities for providing hospitality services in rural households, there are two wine tasting facilities, three excursion sites and three rooms. Apartments, camps and rural holiday homes are not present at all. 
Unfortunately, in the analysed area of the Moslavina region, there are only three tourist information centres (all of which are located in cities Kutina, Ivanić-Grad and Čazma). In all of the other local administration units, no spaces that could be used for such a purpose have been marked for refurbishment or included in planning documents. This significantly diminishes the potential for promoting tourism in the region, as there are no specialised professionals with knowledge of local conditions who could help attract a larger number of tourists to the region.

Furthermore, farmers and owners of family farms who wish to engage in activities related to agrotourism should assess whether their farm is adequate for performing such services, i.e. they should assess the attractiveness of the area in which the farm is located, the appeal of the farm itself and the personalities and willingness of the family members to work with tourists [7].

An analysis of the number of visitors to the Moslavina region in the period from 2010 to 2015 shows that the number has increased by more than 10,000 visitors. The greatest increase was registered from 2011 to 2012, when the number of visitors increased by more than 5,000 people. The largest absolute number of visitors was registered in 2015 . Unfortunately, the increase in the number of visitors was not followed by an increase in the number or quality of accommodation facilities. The accommodation capacity of the analysed are is neither large nor diverse. There is only one hotel per city in the Moslavina region, with less than 200 beds in total, and the majority of the existing hotels are of a lesser category (except for Ivanić Grad, where there is a four-star hotel), which is unacceptable for wealthy guests who demand the highest standards in service and accommodation. Other accommodation facilities, e.g. camps, apartments, studio apartments and accommodation for "Robinson Crusoe"-style tourism, are also not present in the area. The remaining accommodation facilities in the Moslavina region include private rooms ( 8 rooms with 64 beds), holiday homes ( 6 houses with 38 beds), one hostel, one mountain lodge (with 20 beds), three hunting lodges (with 12 beds) and one inn.

Table 7. The number of visits to LAG Moslavina - the number of visitors from 2010 to 2015

\begin{tabular}{lrrrrrr}
\hline \multicolumn{1}{c}{ LAU } & $\mathbf{2 0 1 0}$ & $\mathbf{2 0 1 1}$ & $\mathbf{2 0 1 2}$ & $\mathbf{2 0 1 3}$ & $\mathbf{2 0 1 4}$ & $\mathbf{2 0 1 5}$ \\
\hline City of Kutina & 3,664 & 3,024 & 2,513 & 3,404 & 3,422 & 4,643 \\
\hline $\begin{array}{l}\text { City of Popovača } \\
\text { Lipovljani }\end{array}$ & $\mathrm{N} / \mathrm{A}$ & $\mathrm{N} / \mathrm{A}$ & 1,612 & 2,394 & 2,147 & 2,721 \\
\hline $\begin{array}{l}\text { City of Ivanić } \\
\text { Grad }\end{array}$ & 1014 & 1172 & 4155 & 5184 & 5,507 & 5416 \\
\hline $\begin{array}{l}\text { Križ } \\
\text { Municipality* }\end{array}$ & $580-620$ & $600-620$ & $600-630$ & $650-660$ & $660-700$ & $750-800$ \\
\hline $\begin{array}{l}\text { Garešnica } \\
\text { City of Čazma }\end{array}$ & 800 & 1387 & 2,329 & 2,333 & 2,006 & 2,229 \\
\hline $\begin{array}{l}\text { Kloštar Ivanić } \\
\text { Municipality }\end{array}$ & 8,200 & 8,350 & 8,600 & 8,800 & 8,800 & 9,500 \\
\hline \begin{tabular}{l} 
Total \\
\hline
\end{tabular} & 14,302 & 14,767 & 19,801 & 22,712 & 22,852 & 25,461 \\
\hline
\end{tabular}

The government of the Republic of Croatia is also supporting the development of rural tourism and agrotourism by assuming the obligations for loans given for the purpose of developments under the "Development of Rural Tourism" ("Razvoj turizma na selu") programme. The purpose of the programme is to stimulate the development of tourism in rural areas of Croatia by enhancing the tourist offer through supplementary income- 
generating activities on family farms, but also by increasing the local quality of life and thus creating favourable conditions that would encourage people to remain in rural areas.

Table 8. Hotels in the Moslavina Region

\begin{tabular}{lccc}
\hline \multicolumn{4}{c}{ Hotels (all types) } \\
\hline Town & No. of facilities & No. of beds & Category \\
\hline Kutina & 1 & 96 & 2 \\
\hline Popovača & 1 & 17 & 3 \\
\hline Ivanić-Grad & 1 & 48 & 4 \\
\hline Garešnica & 1 & 32 & 3 \\
\hline Total & 4 & 193 & 3 \\
\hline
\end{tabular}

Source: [14]

The loans are intended for introducing additional accommodation and hospitality facilities for rural tourism, as well as for creating new content and attractions (the "Development of Rural Tourism" crediting programme). It can be concluded from this that the government is using the aforementioned measures to encourage the development of rural tourism and thus brand Croatia as a recognisable rural tourism destination [6]. However, rural tourism also has its downsides, e.g. aggressive intrusions into the natural environment, the social and cultural erosion of rural communities and so on [17].

\section{DEVELOPMENT GOALS}

Agrotourism is a multifunctional form of tourism with great expectations assigned to it. In the eyes of the study participants, this also includes the reduction of business risks in running a family farm, reduced business costs and greater prosperity [10]. Rural tourism has managed to attract increasing interest in parallel with the introduction of new models for rural development on the basis of the reform of agricultural policy, as well as programmes related to policies for the development of tourism [8]. Its goals are as follows:

- the development of innovative ways to utilise tradition and heritage for the creation of new products and services, but also new jobs,

- the development of a sustainable and active form of tourism and recreation by utilising natural, cultural and historical resources

- the development of intersectoral integration with the purpose of developing and promoting local products, especially in agriculture, tourism, crafts and the protection of cultural heritage and natural resources,

- making the area more recognisable by developing autochthonous brands, which will in turn become more recognisable, as well as easier to promote and distribute through new, innovative sales channels,

- the development of human resources and the promotion of lifelong learning and education,

- the development of an adequate social and material infrastructure that would allow for a good quality of life and work for all the inhabitants of the area,

- creating and contributing to a stimulating work and living environment, and

- strengthening cooperation with other locales on the regional, national and international levels andactive participation in the national and EU network of LAGs [15]. 
Unfortunately, despite the numerous measures for development and co-financing, the majority of government incentives and EU funds operate in a way that makes it difficult for farmers with smaller amounts of land to survive in the market, in turn leading to the stance that small holdings have no future in the European Union. According to the data from 2009, 63\% of the 190,000 registered farms have less than 3 ha of land. In their 2003 paper on the issue of fragmentation in agriculture, Franić and Žimbrek state the following: "With approximately 0.65 ha of agricultural and 0.45 ha of arable land per citizen, Croatia is among the countries with abundant agricultural land. Therefore, according to AZO (2011), agricultural land consolidation, from an economic standpoint, has as its goal the improvement of rural areas" [16].

\section{CONCLUSION}

Rural tourism and agrotourism have been present in Europe for a long time. In the last twenty years, these types of tourism have also spread to Croatia. The reasons for this lie in the growing need to further refine agricultural activities and increase income for farmers, as well as to find a way to better promote their products [8]. Rural tourism, which stands for the stay of tourists in households organised as tourist farms for the purposes of rest and relaxation, is one such source of supplementary income that could also help create added value and stimulate the development of both the rural household itself and the surrounding rural area. Moslavina, as a primarily rural region, has very good foundations and resources for the development of this type of tourism, but the main obstacles lie in the relatively small number of young people who could act as a pioneering and stimulating influence, insufficient accommodation capacities primarily based around hotels, too few tourist information centres and the resulting lack of information for potential (and existing) visitors to an area that is certainly worth a visit.Furthermore, the segment of the overall tourist offer that is related to attractions such as cycling and themed routes has not yet been sufficiently developed, although plans are in place for further improvements. To summarise, the development of rural tourism in the Moslavina region will need to overcome great challenges, but the first successful steps have already been taken. With additional investments in infrastructure and people who would be willing to provide this type of tourist services, rural tourism in the Moslavina region certainly has a good future ahead of it.

\section{REFERENCES}

[1] Agriculture Act, Official Gazette of the Republic of Croatia, n.149, 2009 (in Croatian)

[2] Agricultural Census 2003. Croatian Bureau of Statistics, Zagreb, Croatia.

[3] Braičić Z. \& Škriljevečki M. Stavovi i percepcije vlasnika turističkih seoskih obiteljskih gospodarstava o razvojnim potencijalima agroturizma petrinjskog kraja, Praktični menadžment, Croatia, vol. 6(1), pp 152-156, 2015.

[4] Census of Population, Households and Dwellings 2001. Croatian Bureau of Statistics, Zagreb, Croatia.

[5] Census of Population, Households and Dwellings 2011. Croatian Bureau of Statistics, Zagreb, Croatia.

[6] Ćurić K. Agroturizam kao dodatne djelatnosti na obiteljskim poljoprivrednim gospodarstvima, Praktični menadžment, Croatia, vol. 1(1), pp 101-105, 2010. 
[7] Franić R. \& Grgić Z. Agrotourism on a Family Farm in Croatia - Prospects for Development, Agriculturae Conspectus Scientificus, Croatia, vol. 67(3) pp 131-141, 2002.

[8] Franić R. \& Cunj L. Socio-economic Preconditions for Developing Agrotourism in Zagreb County, Agronomy Journal, Croatia, vol. 69(5) pp 381-400, 2007.

[9] Franić R., Kumrić O. \& Hadelan L. The Impact of the Accession to the European Union on Family Farms' Strategic Plans, Agronomy Journal, Croatia, vol. 71(2), pp 161-176, 2009.

[10] Grgić I., Zrakić M. \& Cerjak M. Agrotourism Supply of Zagreb County: Limitations and Possibilities, Agronomy Journal, Croatia, vol. 73(1-2), pp 41-58, 2011.

[11] Hadelan L. \& Franić R. Farm Management as a Factor of Agricultural Competitiveness, Agronomy Journal, Croatia, vol. 68(4), pp 287-304, 2006.

[12] Hospitality and Catering Industry Act, Official Gazette of the Republic of Croatia, n.138, 2006 (in Croatian)

[13] Jelinčić D. A. Agrotourism in European Context, Studia ethnologica Croatica, Croatia, vol. 19(1), pp 269 - 291, 2007.

[14] LAG (Local Action Group) Moslavina, Kutina, Croatia.

[15] Local Development Strategy - LAG Moslavina, Kutina, Croatia, 2013. Retrieved from http://lag-moslavina.hr/wp-content/uploads/2013/03/LRS-Moslavina.pdf

[16] Marković M., Kralik I. \& Peruzović A. Family Farming in the Republic of Croatia Paving the Way for the Laws of Environment Protection in Agricultural Production in European Union, Agronomy Journal, Croatia, vol. 75(4), pp 197-208, 2013.

[17] Oplanić M., Milotić A. \& Ružić P. Family rural economy - the development factor of rural tourism in Istria, Tourism and hospitality management, Croatia, vol. 3(2), pp 427-440, 1997.

[18] Ordinance on the Performance of Hospitality Services in Rural Households, Official Gazette of the Republic of Croatia, n.5, 2011 (in Croatian)

[19] Program kreditiranja seoskog turizma "Razvoj turizma na selu". Ministarstvo turizma, Zagreb, Croatia. Retrieved from http://www.mint.hr/UserDocsImages/090422seoskiturizam.pdf

[20] Tourism Act, Official Gazette of the Republic of Croatia, n.8, 1996 (in Croatian)

[21] http://www.dzzp.hr

[22] http://www.savjetodavna.hr/

[23] http://portal.hrsume.hr/index.php/hr/ 